\title{
PERBEDAAN HASIL BELAJAR DAN AKTIVITAS SISWA MENGGUNAKAN MODEL PEMBELAJARAN TIPE JIGSAW DAN TIPE ROLE PLAYING PADA MATERI SISTEM PEREDARAN DARAH MANUSIA KELAS XI IPA SMAN 3 PEMATANGSIANTAR
}

\author{
Desy Putri Sari ${ }^{*}$, Ely Djulia \\ Program Studi Pendidikan Biologi, Universitas Negeri Medan \\ Jl. William Iskandar Pasar V Medan Estate, Medan, Indonesia \\ *Email: desyp490@gmail.com
}

\begin{abstract}
ABSTRAK
Penelitian ini bertujuan untuk mengetahui perbedaan hasil belajar siswa dan aktivitas belajar siswa dengan menggunakan model pembelajaran Jigsaw dan model pembelajaran Role Playing pada materi Sistem Peredaran Darah Manusia di SMA Negeri 3 Pematangsiantar.Penelitian ini termasuk jenis penelitian quasi eksperimen dengan desain two group pre-test and post-test. Populasinya adalah seluruh siswa kelas XI IPA SMA Negeri 3 Pematangsiantar yang terdiri dari 7 kelas. Pengambilan sampel dilakukan dengan cara purposive sampling, sampel diambil dari populasi sebanyak dua kelas karena adanya kelas bersifat heterogen (unggulan) dan pemilihan sampel berdasarkan petunjuk dari guru pembimbing dan pihak sekolah. Instrumen yang digunakan adalah tes hasil belajar sebanyak 25 soal serta lembar observasi aktivitas siswa. Kelas XI IPA 3 diberikan perlakuan dengan model pembelajaran Role Playing. Kelas XI IPA 5 diberikan perlakuan dengan model pembelajaran Jigsaw. Dari hasil perhitungan uji-t dua pihak diperoleh $t_{\text {hitung }}=3,30$ dan $t_{\text {tabel }}=1,99$, sehingga $t_{\text {hitung }}>t_{\text {tabel. }}$. Perolehan data menunjukkan bahwa ada perbedaan yang signifikan antara model pembelajaran tipe Jigsaw dan Role Playing terhadap hasil belajar dan aktivitas belajar siswa pada materi Sistem Peredaran Darah Manusia di kelas XI IPA SMA Negeri 3 Pematangsiantar. Dimana kelas yang diajarkan dengan model pembelajaran Jigsaw memperoleh hasil belajar yang lebih tinggi daripada kelas yang diajarkan dengan model pembelajaran Role Playing. Aktivitas siswa pada pembelajaran tipe Jigsaw dan Role Playing dapat dikategorikan cukup aktif.
\end{abstract}

Kata kunci : Jigsaw, Role Playing, hasil belajar, aktivitas belajar siswa

\section{ABSTRACT}

This study aims to determine the differences of student learning outcomes and student learning activities using Jigsaw learning model and Role Playing learning model on Human Circulatory Systems in SMA 3 Pematangsiantar.This type of research is quasi-experimental with two group pre-test and post-test design. The population is all students of class XI IPA SMA Negeri 3 Pematangsiantar consisting of 7 classes. Sampling is done by purposive sampling, the sample is taken from the population as much as two classes because of the class is heterogeneous (superior) and the selection of samples based on the instructions of the tutors and the school. The instrument used for the test result of learning as much as 25 questions and student activity observation sheet. Class XI IPA 3 is given treatment with Role Playing learning model. Class XI IPA 5 is given treatment with Jigsaw learning model. From the calculation result of $t$-test two parties obtained $t_{\text {count }}=3.30$ and $t_{\text {table }}=1.99$, so $t_{\text {count }}>t_{\text {table. }}$. Data acquisition shows that there is a significant difference between Jigsaw and Role Playing type of learning model on learning outcomes and student learning activities on Human Circulatory System material in class XI IPA SMA Negeri 3 Pematangsiantar. Where classes taught by the Jigsaw learning model get higher learning outcomes than the classes taught by the Role Playing learning model. Student activity on Jigsaw type and Role Playing learning can be categorized quite actively.

Keywords: Jigsaw, Role Playing, learning outcomes, student learning activities.

\section{PENDAHULUAN}

Dalam kehidupan sehari-hari, bila kita menyebut darah, hal itu diidentikkan dengan darah yang berwarna merah. Padahal warna merah pada darah itu tidak selalu tetap, artinya warna itu bisa berubah-ubah. Terkadang darah cenderung berwarna merah tua, namun terkadang berwarna merah muda. Darah adalah komponen yang sangat penting bagi makhluk hidup, karena mempunyai peran yang sangat banyak, terutama dalam pengangkutan zat-zat yang penting bagi proses metabolisme tubuh. Jika darah mengalami gangguan, maka segala proses metabolisme tubuh akan terganggu pula (Lestari,2009:138).

Adanya masalah utama dalam pembelajaran pada pendidikan formal sekarang ini adalah masih rendahnya daya serap peserta didik, sehingga hasil 
belajar siswa masih rendah. Dominannya metode ceramah dalam kegiatan pembelajaran biologi bisa menyebabkan proses kegiatan belajar mengajar akan terasa membosankan bagi siswa karena terasa monoton. Kondisi ini diduga akan sangat mempengaruhi keaktifan siswa didalam kelas. Untuk mengantisipasi masalah tersebut guru dituntut untuk melakukan inovasi dalam proses pembelajaran. Inovasi tersebut antara lain dengan menerapkan model-model pembelajaran inovatif yang diharapkan mampu meningkatkan kualitas proses dan hasil belajar. Model pembelajaran yang digunakan pada proses pembelajaran menentukan hasil belajar yang didapat oleh siswa. Adapun hasil belajar siswa berpengaruh terhadap nilai Kriteria Ketuntasan Minimum (KKM) yang ditentukan oleh sekolah (Hasruddin,2015:10).

Berdasarkan hasil observasi awal di SMA Negeri 3 Pematangsiantar, bahwa proses belajar mengajar di kelas dilakukan menggunakan metode ceramah, diskusi dan pemberian tugas. Dalam proses pembelajaran di SMA Negeri 3 Pematangsiantar, guru menjelaskan materi pelajaran dan mengadakan tanya jawab kepada siswa. Metode pembelajaran yang digunakan guru di sekolah yaitu metode diskusi, dan ceramah. Sehingga banyak siswa yang merasa jenuh dalam mengikuti proses belajar mengajar. Pembelajaran di SMA Negeri 3 Pematangsiantar juga menggunakan presentasi kelompok di depan kelas dan proses tanya jawab. Mencatat yang dilakukan siswa adalah dengan mengkopi langsung dari buku pelajarannya sehingga siswa mengalami kebosanan dan aktivitasnya kurang. Sehingga pada saat pembelajaran siswa kurang merespon materi yang diajarkan. Terkhusus pada materi Sistem Peredaran Darah Manusia yang memerlukan pemahaman terhadap organ-organ serta proses pada sistem peredaran darah manusia. Metode pembelajaran yang demikian dampaknya terlihat dari prestasi belajar yang secara umum masih kurang memuaskan.

Berdasarkan informasi guru biologi di SMA Negeri 3 Pematangsiantar diketahui bahwa Kriteria Ketuntasan Minimal (KKM) mata pelajaran biologi adalah 72. Hasil dari wawancara dengan guru biologi yang ada di sekolah bahwa hanya sebagian siswa yang mencapai KKM dan siswa yang tidak mencapai KKM sebanyak 65 \% dengan rata-rata 50 untuk materi sistem peredaran darah manusia. Berdasarkan hasil wawancara tersebut siswa sudah paham dalam menyebutkan fungsi dari alat-alat peredaran darah dan penyakit-penyakit pada sistem peredaran darah. Tetapi siswa masih kurang paham terhadap struktur dari alat-alat peredaran darah serta menjelaskan macam-macam proses peredaran darah didalam tubuh manusia.

Model pembelajaran tipe Jigsaw digunakan guru untuk memudahkan dalam mengetahui materi pelajaran berupa konsep yang akan memudahkan dan meningkatkan aktivitas siswa dalam proses pembelajaran. Role Playing digunakan untuk membangkitkan minat siswa dan dapat menyemangati siswa yang memiliki sudut pandang yang berbeda, karena seluruh siswa terlibat di dalam peran mereka. Sehingga dapat membantu siswa lebih cepat untuk paham dalam pembelajaran biologi melalui bermain peran terutama pada materi sistem peredaran darah di SMA Negeri 3 Pematangsiantar, sehingga peneliti ingin menerapkannya dalam menyampaikan materi di dalam kelas, agar siswa dapat memperoleh hasil belajar yang baik.

Pemilihan model pembelajaran Jigsaw sebagai model pembelajaran yang akan digunakan dalam penelitian ini juga didukung oleh jurnal hasil penelitian yang dilakukan oleh Masparingga dan Awal (2013) yang berjudul Penerapan Model Pembelajaran Kooperatif Tipe Jigsaw Untuk Meningkatkan Hasil Belajar Siswa Kelas XI IPA SMA Nurul Falah Pekanbaru pada tahun 2013. Setelah dilakukan proses pembelajaran kooperatif tipe Jigsaw pada kelas eksperimen diperoleh data rerata pretest pada kelas kontrol 9,33, sedangkan pada kelas eksperimen 9,36. Rerata $N$-Gain pada kelas eksperimen 0,78 kategori tinggi, sedangkan pada kelas kontrol 0,56 dikategorikan sedang. Dengan demikian dapat disimpulkan bahwa penggunaan model pembelajaran kooperatif tipe Jigsaw dapat meningkatkan hasil belajar siswa pada kelas XI IPA SMA Nurul Falah Pekanbaru.

Pemilihan model pembelajaran Role Playing sebagai model pembelajaran yang akan digunakan dalam penelitian ini juga didukung oleh jurnal hasil penelitian yang dilakukan oleh Rivandinia I.H, Subchan W, Asyiah I.N (2014) yang berjudul Penggunaan Model Pembelajaran Role Playing Untuk Peningkatan Hasil Belajar dan Aktivitas Siswa Pada Mata Pelajaran Biologi (Standar Kompetensi Memahami Saling Ketergantungan 
dalam Ekosistem) di SMP Negeri 1 Tapen Kabupaten Bondowoso. Hasil penelitian menunjukkan model pembelajaran Role Playing meningkatkan aktivitas siswa di kelas. Rata-rata nilai aktivitas siswa dari siklus I ke siklus II juga mengalami peningkatan yaitu dari 69,29 menjadi 74,41 . Standar deviasi pada siklus I adalah 76,02 dan pada siklus II menjadi 8,12 hal tersebut menandakan data yang diperoleh dari hasil observasi cukup representatif, karena besarnya standar deviasi lebih rendah daripada besarnya mean nilai aktivitas siswa.

Berdasarkan uraian dan latar belakang diatas, peneliti tertarik untuk melakukan penelitian tentang "Perbedaan Hasil Belajar dan Aktivitas Siswa Menggunakan Model Pembelajaran Tipe Jigsaw dan Tipe Role Playing Pada Materi Sistem Peredaran Darah Manusia Kelas XI IPA SMAN 3 Pematangsiantar"

\section{METODE PENELITIAN}

$\begin{array}{rrr}\text { Penelitian ini dilaksanakan di SMAN } 3 \\ \text { Pematangsiantar } & \text { Jln.Pane } & \text { No.251 }\end{array}$ Pematangsiantar. Waktu penelitian dimulai bulan Agustus-Oktober 2017 di kelas XI IPA SMAN 3 Pematangsiantar. Populasi dalam penelitian ini adalah semua siswa kelas XI IPA SMAN 3 Pematangsiantar yang berjumlah tujuh kelas. Menggunakan teknik purposive sampling, sampel diambil dari populasi sebanyak dua kelas karena adanya kelas bersifat heterogen (unggulan) dan pemilihan sampel berdasarkan petunjuk dari guru pembimbing dan pihak sekolah. Satu kelas yakni kelas XI IPA 3 dan satu kelas lagi yakni kelas XI IPA 5 dengan jumlah siswa 64 siswa. Jenis penelitian ini adalah penelitian quasi eksperimen. Sampel yang diambil dalam penelitian ini dibagi menjadi dua kelompok. Masing-masing kelompok diberi perlakuan. Untuk kelompok I (XI IPA 5) diberi perlakuan yaitu mengajar materi Sistem Peredaran Darah Manusia dengan menggunakan model Jigsaw sedangkan untuk kelompok II (XI IPA 3) diberi perlakuan yaitu mengajar materi Sistem Peredaran Darah Manusia dengan menggunakan model Role Playing.

Instrumen penelitian yang digunakan dalam penelitian ini adalah tes dan non tes. Tes yang digunakan untuk memperoleh data hasil belajar siswa adalah tes objektif yang berbentuk pilihan berganda berjumlah 25 soal. Namun sebelum instrument soal dipakai pada kelas eksperimen, terlebih dahulu diujicoba di luar sampel penelitian untuk menguji kelayakan soal, yaitu dengan menguji validitas, reliabilitas, tingkat kesukaran dan daya beda soal. Berdasarkan hasil pengujian ini dihasdilkan 25 soal yang layak dipakai untuk instrument penelitian. Non tes yang digunakan berupa lembar observasi yang dirancang untuk mengumpulkan data mengenai aktivitas siswa dengan menggunakan dua observer selama pembelajaran dengan menggunakan model Jigsaw dan Role playing.

Dalam penelitian ini untuk memperoleh data yang diperlukan peneliti menggunakan alat pengumpul data berupa pretest dan postes. Kegiatan yang dilakukan yaitu peneliti memberikan pretest dalam bentuk tes objektif pada kedua kelompok kelas. Melaksanakan pengajaran dengan materi sistem peredaran darah dimana kelompok I pembelajaran materi ekosistem menggunakan model Jigsaw dan pada kelompok II pembelajaran dengan menggunakan Role Playing. Setelah pelaksanaan pengajaran selesai, maka diadakan tes akhir (Postes) dalam bentuk objektif tes bagi masing masing siswa untuk mengetahui hasil belajar siswa. Hasil postes diperiksa dan ditabulasikan dalam tabel data untuk memperoleh kesimpulan tentang perbedaan model pembelajaran pada hasil belajar siswa tersebut. Untuk penilaian aktivitas siswa, saat melaksanakan pengajaran aktivitas siswa diamati oleh observer dan dinilai sesuai lembar aktivitas siswa yang ada.

Data yang diolah dalam penelitian ini yaitu hasil belajar dari kelas eksperimen I (menggunakan Model Jigsaw) dan kelas eksperimen II (menggunakan Model Role Playing). Teknik analisis data yang digunakan adalah analisis perbedaan dengan menggunakan rumus uji t.Sebelum uji $t$, data ditabulasikan dengan menghitung jumlah skor pretes dan postes dari kedua kelas sampel, nilai rata-rata kedua kelas, varians sampel. Syaratsyarat yang diperlukan untuk menghitung rata-rata dan simpangan baku adalah populasi harus berdistribusi normal dan harus homogen. 
Halaman : $047-053$

\section{HASIL PENELITIAN}

\section{Data Tes Hasil Belajar Siswa}

Penelitian ini dilakukan di kelas XI IPA dimana XI IPA 3 (model pembelajaran Role Playing) dan XI
IPA 5 (model pembelajaran Jigsaw). Dari data hasil penelitian, diperoleh rata-rata dan standar deviasi dari hasil belajar siswa seperti terlihat pada Tabel 1.

Tabel 1. Rata-rata dan Standar Deviasi Hasil Belajar Kelas Jigsaw dan Kelas Role Playing

\begin{tabular}{cccccccc}
\hline & \multicolumn{3}{c}{ Kelas Jigsaw } & \multicolumn{4}{c}{ Kelas Role Playing } \\
\hline \multicolumn{2}{c}{ Pretes } & \multicolumn{2}{c}{ Postes } & \multicolumn{2}{c}{ Pretes } & \multicolumn{2}{c}{ Postes } \\
\hline $\bar{X}$ & SD & $\bar{X}$ & SD & $\bar{X}$ & SD & $\bar{X}$ & SD \\
34,5 & 12,92 & 75,125 & 7,09 & 40,5 & 14,32 & 68,75 & 8,28 \\
\hline
\end{tabular}

Dari data tabel rata-rata nilai pretes pada kelas Jigsaw adalah 34,5 , sementara rata-rata nilai pretes pada kelas Role Playing adalah 40,5. Dari hasil tersebut diperoleh bahwa nilai rata-rata kelas Jigsaw lebih rendah daripada kelas Role Playing. Dengan uji normalitas dan homogenitas yang dilakukan, didapatkan bahwa nilai pretest dari kedua kelas berdistribusi normal dan homogen. Dengan uji hipotesis yang dilakukan, didapatkan kemampuan awal siswa pada kedua kelas sama sebelum diberikan model pembelajaran Jigsaw dan Role Playing.

Rata-rata nilai postes pada kelas Jigsaw adalah 75,125 , sementara rata-rata nilai postes pada kelas Role Playing adalah 68,75. Dari hasil tersebut diperoleh bahwa nilai rata-rata kelas Jigsaw lebih tinggi daripada kelas Role Playing. Dengan uji normalitas dan homogenitas yang dilakukan, didapatkan bahwa nilai postes dari kedua kelas berdistribusi normal dan homogen. Dengan uji hipotesis yang dilakukan, terdapat perbedaan hasil belajar pada kedua kelas yaitu pada kelas Jigsaw dan kelas Role Playing.

Perbedaan hasil belajar siswa dikelas Jigsaw dan kelas Role Playing dapat dilihat pada Gambar 1 (hasil belajar berdasarkan Taksonomi Bloom), dan Gambar 2 (hasil belajar berdasarkan indikator pembelajaran).

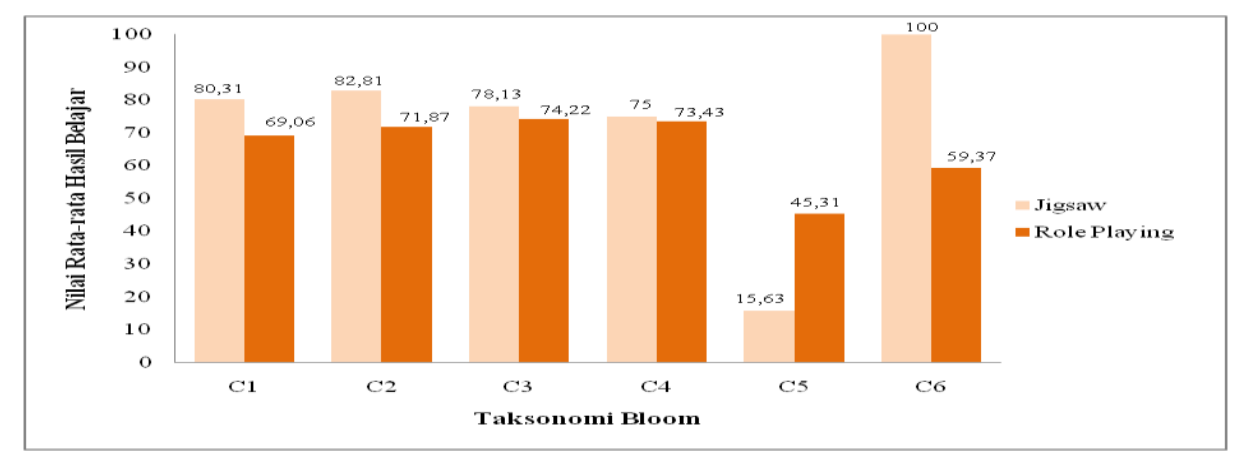

Gambar 1. Hasil Belajar Kelas Jigsaw dan Kelas Role Playing berdasarkan Taksonomi Bloom

Dari data diatas soal C5 memiliki nilai hasil belajar begitu rendah baik dikelas Jigsaw atau dikelas Role Playing dikarenakan tidak banyak siswa yang dapat menjawab soal yang berkategori C5 dengan benar, sehingga diperoleh nilai yang lebih rendah dibandingkan soal kategori C1,C2,C3,C4 dan C6. 


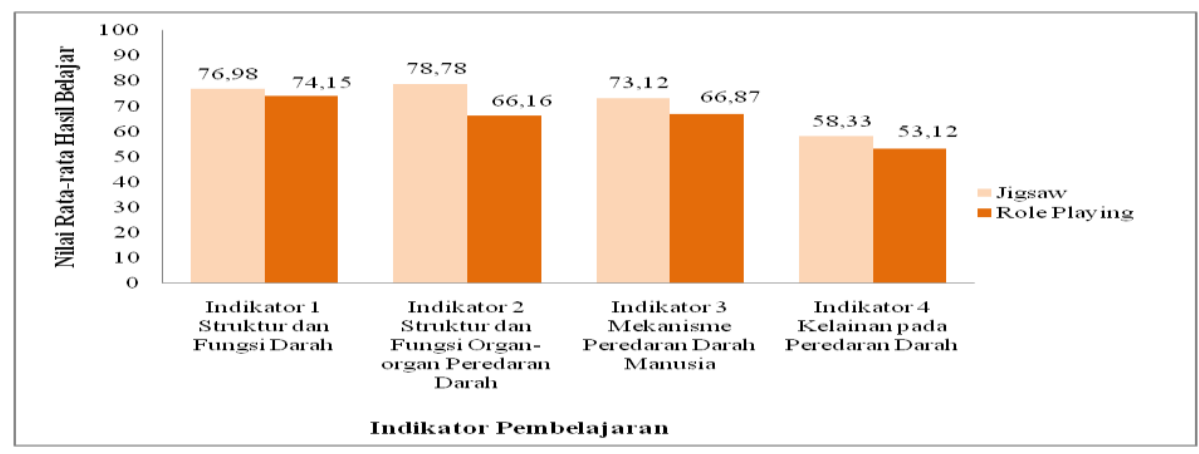

Gambar 2. Hasil Belajar Siswa Kelas Jigsaw dan Kelas Role Playing berdasarkan indikator pembelajaran

Nilai rata-rata hasil belajar siswa berdasarkan indikator pembelajaran menunjukkan kelas jigsaw lebih unggul dari pada kelas role playing untuk keempat indikator pembelajaran pada materi sistem peredaran darah manusia. Dimana untuk indikator 1 kelas jigsaw memperoleh 76,98 sedangkan kelas role playing sebesar 74,15. Pada indikator 2 kelas jigsaw memperoleh 78,78 sedangkan kelas role playing sebesar 66,16. Pada indikator 3 kelas jigsaw memperoleh 73,12 sedangkan kelas role playing sebesar 66,87. Pada indikator 4 kelas jigsaw memperoleh 58,33 sedangkan kelas role playing sebesar 53,12.

\section{Analisis Data Aktivitas Belajar Siswa}

Aktivitas belajar siswa diamati oleh dua observer yaitu teman peneliti. Diperoleh skor ratarata aktivitas belajar pada kelas Jigsaw dan kelas Role Playing pada pertemuan 1 sampai pertemuan 3 dapat dilihat pada Tabel 2.

Tabel 2. Skor aktivitas belajar siswa Kelas Jigsaw dan Kelas Role Playing

\begin{tabular}{ccc}
\hline Pertemuan & Kelas Jigsaw & Kelas Role Playing \\
\hline I & 60,63 & 48,54 \\
II & 67,71 & 52,29 \\
III & 70 & 57,71 \\
\hline Rata-rata & $66,11 \%$ & $52,84 \%$ \\
\hline
\end{tabular}

Dari tabel diperoleh skor rata-rata aktivitas siswa di kelas Jigsaw selama 3 pertemuan ialah $66,11 \%$, yang dapat diklasifikasikan sebagai kategori cukup aktif. Sedangkan skor rata-rata aktivitas siswa di kelas Role Playing selama 3 pertemuan ialah 52,84\%, yang dapat diklasifikasikan sebagai kategori cukup aktif.

Aktivitas siswa yang terjadi di kelas Jigsaw berupa kerjasama siswa dalam kelompok asal, keberanian siswa dalam mengemukakan pendapat dalam kelompok asal, kerjasama siswa dalam kelompok ahli, keberanian siswa dalam mengemukakan pendapat dalam kelompok ahli, serta mempresentasikan hasil kerja dalam kelompok asal. Sedangkan aktivitas siswa yang terjadi di kelas Role Playing berupa membaca skenario, keberanian memilih peran, menghayati peran, mendemonstraikan peran, serta mengemukakan pendapat terhadap penampilan. Perbedaan aktivitas siswa dikelas Jigsaw dan kelas Role Playing dapat dilihat pada Gambar 3. (aktivitas siswa keseluruhan). 
Halaman : 047 - 053

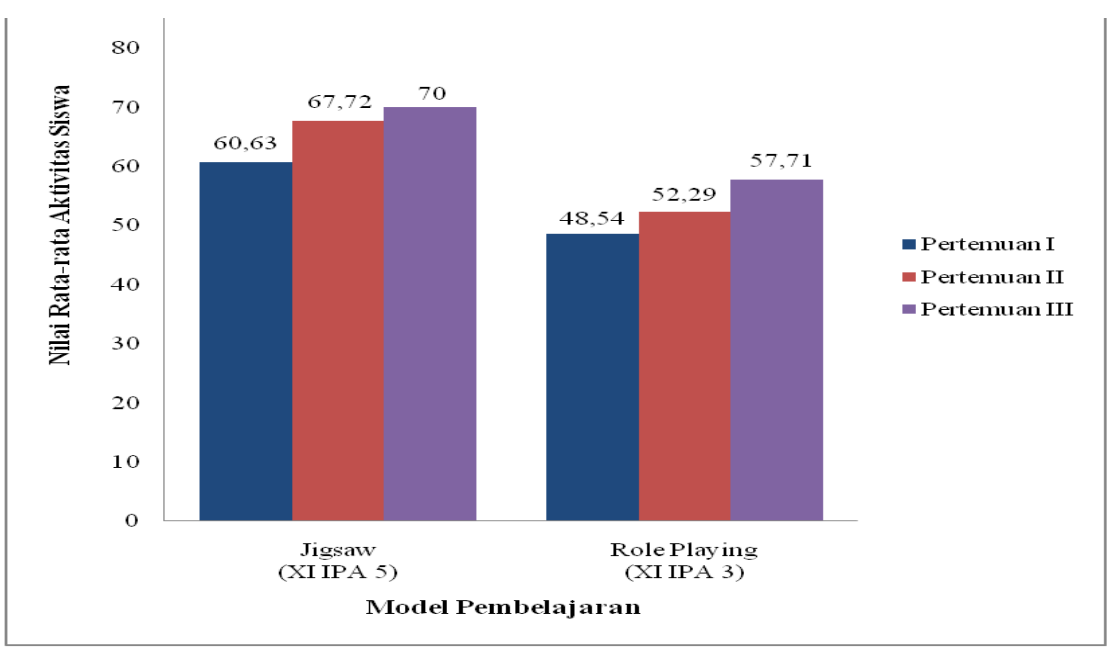

Gambar 3. Aktivitas Siswa Kelas Jigsaw dan Kelas Role Playing

Dari gambar di atas diperoleh nilai rata-rata aktivitas siswa di kelas Jigsaw pada pertemuan I sebesar 60,63; pertemuan II sebesar 67,72; pertemuan III sebesar 70 yang mengalami peningkatan setiap pertemuan. Sedangkan nilai rata-rata aktivitas siswa di kelas Role Playing pada pertemuan I sebesar 48,54; pertemuan II sebesar 52,29; pertemuan III sebesar 57,71 yang mengalami peningkatan setiap pertemuan.

\section{PEMBAHASAN}

Perbedaan hasil belajar di kelas Jigsaw dan kelas
Role Playing
Dari hasil penelitian yang dilakukan menunjukkan bahwa ada perbedaan rata-rata hasil belajar serta aktivitas belajar siswa yang signifikan antara siswa yang diajar dengan menggunakan model pembelajaran jigsaw dengan siswa yang diajar dengan menggunakan model pembelajaran role playing. Hal ini dapat dilihat dari rata-rata hasil belajar di kelas jigsaw yaitu 75,125 dan rata-rata hasil belajar di kelas role playing yaitu 68,75 .

Hasil belajar siswa berdasarkan indikator pembelajaran menunjukkan kelas jigsaw lebih unggul dari pada kelas role playing untuk keempat indikator pembelajaran pada materi sistem peredaran darah manusia. Dimana untuk indikator 1 mengenai struktur dan fungsi dari darah kelas jigsaw memperoleh 76,98 sedangkan kelas role playing sebesar 74,15. Pada indikator 2 mengenai struktur dan fungsi dari organ-organ peredaran darah manusia kelas jigsaw memperoleh 78,78 sedangkan kelas role playing sebesar 66,16 . Pada indikator 3 mengenai mekanisme peredaran darah manusia kelas jigsaw memperoleh 73,12 sedangkan kelas role playing sebesar 66,87. Pada indikator 4 mengenai kelainan pada sistem peredaran darah manusia kelas jigsaw memperoleh 58,33 sedangkan kelas role playing sebesar 53,12.

Penelitian sebelumnya yang mendukung penelitian ini yaitu penelitian yang dilakukan oleh Satria,Oktavia dan Hera (2015) yang berjudul Penerapan Model Pembelajaran Kooperatif Tipe Jigsaw untuk Meningkatkan Hasil Belajar Siswa Kelas VII Padamateri Sistem Pencernaan Manusia di SMP Negeri 3 Meureubo. Berdasarkan hasil penelitian dapat disimpulkan bahwa pembelajaran kooperative tipe jigsaw dapat meningkatkan hasil belajar siswa kelas VII SMP N 3 Meurubo pada pembelajaran Biologi. Hal ini terbukti dari: (1) hasil belajar siswa berdasarkan observasi pada siklus I adalah (kategori cukup) meningkat pada siklus II menjadi (kategori tinggi). hasil belajar siswa berdasarkan angket pada siklus I adalah (kategori cukup) meningkat pada siklus II menjadi (kategori tinggi) (2) hasil tes hasil belajar siswa nilai siswa pra tindakan sebesar $10 \%$ (kategori kurang) meningkat pada siklus I menjadi $40 \%$ (kategori cukup), dan pada siklus II menjadi 90\% (kategori tinggi) .

\section{Perbedaan aktivitas siswa di kelas Jigsaw dan kelas Role Playing}

Aktivitas belajar pada kelas jigsaw dan role playing yang diamati selama proses pembelajaran terdapat perbedaan dan mengalami peningkatan meskipun masih dalam kategori cukup aktif. Pada pembelajaran jigsaw aktivitas siswa pertemuan I ialah 60,63 , pada pertemuan II ialah 67,71 dan 
pada pertemuan III ialah 70. Sedangkan pada pembelajaran role playing aktivitas siswa pertemuan I ialah 48,54, pada pertemuan II ialah 52,29 dan pada pertemuan III ialah 57,71. Dari hasil pengamatan dapat diketahui bahwa aktivitas siswa pada pembelajaran jigsaw lebih tinggi dari pada aktivitas siswa pada pembelajaran role playing.

Hal ini sejalan dengan penelitian yang dilakukan oleh Suparman, Wondal dan Djamrud (2014) Hasil dan analisis data menunjukkan bahwa penerapan model pembelajaran kooperatif tipe jigsaw pada materi pencemaran lingkungan dapat meningkatkan aktivitas dan hasil belajar siswa kelas VII SMPN I Sahu tahun pelajaran 2013/2014 pada materi pencemaran lingkungan. Presentase aktivitas belajar siswa pada siklus I sebesar 51,82\% meningkat menjadi $83,32 \%$ pada siklus II. Sedangkan presentase ketuntasan belajar pada siklus I di peroleh nilai rata-rata $16,85 \%$ kemudian meningkat dengan nilai rata-rata tes siklus II yaitu $81,45 \%$.

\section{KESIMPULAN}

Hasil belajar siswa dengan menggunakan model pembelajaran tipe Jigsaw pada materi Sistem Peredaran Darah Manusia diperoleh rata rata sebesar 75,125 dan aktivitas siswa dikategorikan cukup aktif dengan rata - rata sebesar 66,11 \%. Hasil belajar siswa dengan menggunakan model pembelajaran tipe Role Playing pada materi Sistem Peredaran Darah Manusia diperoleh rata - rata sebesar 68,75 dan aktivitas siswa dikategorikan cukup aktif dengan rata - rata sebesar 52,84 \%. Dari hasil perhitungan uji-t dua pihak diperoleh $t_{\text {hitung }}=3,30$ dan $t_{\text {tabel }}=$ 1,99, sehingga $t_{\text {hitung }}>t_{\text {tabel. }}$. Perolehan data menunjukkan bahwa ada perbedaan yang signifikan antara model pembelajaran tipe Jigsaw dan Role Playing terhadap hasil belajar dan aktivitas belajar siswa pada materi Sistem Peredaran Darah Manusia di kelas XI IPA SMA Negeri 3 Pematangsiantar.

\section{DAFTAR PUSTAKA}

Arikunto , S., (2011), Dasar-Dasar Evaluasi Pendidikan, PT. Bumi Aksara, Jakarta.
Hasruddin dan Situmorang. T.H., (2015), Perbedaan Hasil Belajar Siswa Yang Diajarkan Menggunakan Model Pembelajaran Project Based Learning Dengan Problem Based Learning Pada Materi Ekosistem Di Kelas X SMA Negeri 2 Lubuk Pakam Tahun Pembelajaran 2014/2015. Jurnal Pelita Pendidikan, 4(3) : 010-019.

Joyce, B., (2009), Model of Teaching, Pustaka Belajar, Yogyakarta.

Masparingga dan Awal., (2013), Penerapan Model Pembelajaran Kooperatif Tipe Jigsaw Untuk Meningkatkan Hasil Belajar Siswa Kelas XI IPA SMA Nurul Falah Pekanbaru. Lectura, 4(01) : 54-62.

Satria,Oktavia dan Hera., (2015), Penerapan Model Pembelajaran Kooperatif Tipe Jigsaw untuk Meningkatkan Hasil Belajar Siswa Kelas VII Padamateri Sistem Pencernaan Manusia di SMP Negeri 3 Meureubo. Jurnal Bionatural, 2(2) : 37-48.

Suparman, Wondal dan Djamrud., (2014), Penerapan Model Pembelajaran Kooperatif Tipe Jigsaw Untuk Meningkatkan Aktivitas dan Hasil Belajar IPA Pada Konsep Pencemaran Lingkungan. Jurnal Bioedukasi, 3(1) : 293-298.

Rivandinia I.H, Subchan W, Asyiah I.N., (2014), Penggunaan Model Pembelajaran Role Playing Untuk Peningkatan Hasil Belajar dan Aktivitas Siswa Pada Mata Pelajaran Biologi (Standar Kompetensi Memahami Saling Ketergantungan dalam Ekosistem) di SMP Negeri 1 Tapen Kabupaten Bondowoso. Pancaran, 3(3) : 63-72. 